水痘後に発症した一側高度感音難聴症例

原田勇彦・山岨 達也

八木 真人・川端五十鈴*

\title{
Unilateral Profound Deafness following Chickenpox Infection; A Case Report
}

\author{
Takehiko Harada, Tatsuya Yamasoba and Masato Yagi \\ (University of Tokyo) \\ Isuzu Kawabata \\ (Saitama Medical Center, Saitama Medical School)
}

\begin{abstract}
This paper reports on a case of unilateral profound deafness which occurred following chickenpox infection. A 5-year-old boy's hearing had been found to be normal by pure tone audiometry before he contracted chickenpox. After the infection, which was confirmed by an antibody titer rise in the serum, the patient was found to be profoundly deaf in his left ear. The similarity of the clinical features of this case to those of deafness following mumps allows us to suppose that a similar pathology underlies these two types of deafness. A review of the literature revealed only two detailed reports of such cases, while several other reports indicated a low incidence of deafness following chickenpox. Accumulation of more such cases is necessary to elucidate the clinical picture of this type of deafness.
\end{abstract}

Key words: deafness, chickenpox, labyrinthitis

\section{はじめに}

ある種のウイルスが難聴をおこすことはよく 知られている．胎児に感染して先天性難聴をき たすととでは風疹ウイルスやサイトメガロウイ ルスなどが知られて抢り，生後に感染して後天 性難聴をきたすウイルスとしてはムンプス，麻 疹，水痘，インフルェンザなどのウイルスが指 摘されている。 このうち水痘ウイルスによる難 聴については招もに成人に招きる耳性带状泡疹

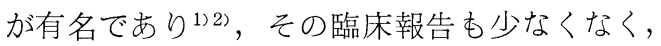
またヒトに括ける側頭骨病理の報告もなされて
いる374. しかしながら小児における水痘による 難聴については, 一部の耳鼻咽喉科学教科書に 記載はあるあののその詳細については不明であ $り^{5)}$ ，神経学教科書をみても水痘の合併症とし ての難聴の記載はない(6).

最近，著者らは水痘罹患後に発症した一側高 度感音難聴の一症例を経験した。乙うした症例 報告がきわめて少ない現状を考慮すると本症例 は非常に貴重と思われるので，乙こにその詳細 を報告し，あわせて文献的考察を加える. 


\section{症例報告}

症例 : 5 歳, 男児.

主訴：左難聴.

現病歴：昭和63年12月に母親が難聴に気付き， 昭和64年 1 月 4 日に埼玉医科大学総合医療セン ター耳鼻咽喉科を受診した。このときは両側に 滲出性中耳炎を認めオージオグラムは四 $1 \mathrm{~A} の$ ようであった。鼻処置, 通気, 投薬による保存 的療法で聴力は図 $1 \mathrm{~B}$ のように改善した. 平成 元年 4 月19日に水痘に罹患し，近くの小児科医 で治療を受けて4月24日にはほぼ治癒した。し かしながらその後に聞き返しがふえ，4月27日 に母親がイヤホンで確かめたところ左の難聴が 疑われたため，5月11日に同センターを受診し た。このとき左高度感音難聴を認めたため当科 を紹介され，5月19日に初診した。

既往歴: 平成元年 3 月 29 日に後頭部皮膚肉芽 腫の切除術をうけている. 3 歳で風疹に罹患し たが，麻疹と流行性耳下腺炎は予防接種を受け ており罹患の既往はない.

家族歴：平成元年 4 月上旬, 患児が罹患する 直前に姉屯水痘に罹患しているが，難聴はきた していない.

初診時所見：両側鼓膜は正常で，他にあ耳鼻 咽喉科的異常, 全身的異常を認めなかった。

検査結果：オージグラムは眓 2 亿示すように， 右は正常聴力であるのに対して左は壟に近かっ た.ティンパノグラムは両側共に AS 型を示し たが，あぶみ骨筋反射では右耳刺激で正常閾值 の反応がみられたのに対して，左耳刺激では反 応はみられなかった。 温度眼振検査では両耳共 に正常反応を示した．5月19日と6月 6 日に测 定したウイルス抗体值を表 1 に示す。水痘ウイ ルスの抗体価は 2 回共32倍と高值を示し, 水痘
罹患を証明している. 一方，ムンプス抗体価は 陰性であった。

治療経過：5月22日から 5 月 31 日まで入院し， ステロイドを中心とする点滴治療を行ったが, 難聴の改善は認められなかった，退院後の経過 観察であ同様であった。

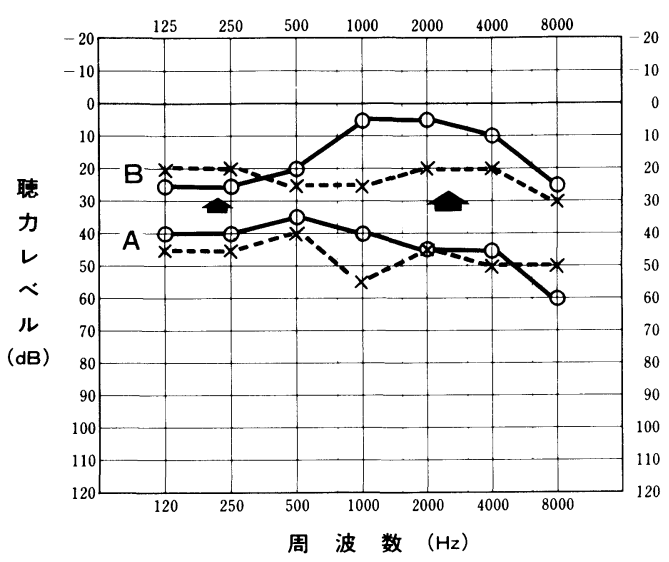

図 1 滲出性中耳炎治療時のオージオグラム （伝音難聴 骨導は略）

A：昭和64年 1 月 4 日 治療前

$\mathrm{B}$ : 平成元年 3 月 4 日 治療後

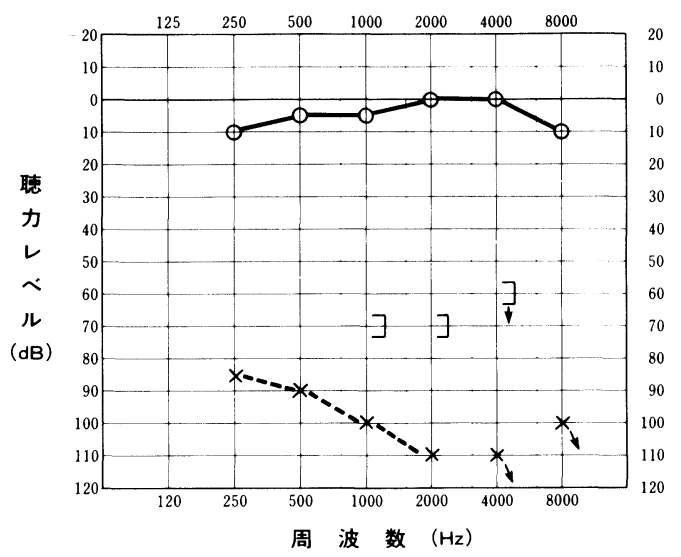

図 2 当科初診時のオージオグラム

表 1 血清ウイルス抗体価

\begin{tabular}{|c|c|c|c|c|c|c|c|}
\hline & ムンプス & $\begin{array}{l}\text { 単 純 } \\
\text { ヘルペス }\end{array}$ & 水 痘 & 麻 疹 & $\begin{array}{l}\text { マイ } \\
\text { プラズマ }\end{array}$ & $\begin{array}{l}\text { サイト } \\
\text { メガロ }\end{array}$ & 風 疹 \\
\hline 5 月19日 & 4 & 4 & 32 & - & 16 & 8 & 256 \\
\hline 6 月 6 日 & 4 & 4 & 32 & 4 & 16 & 8 & 256 \\
\hline
\end{tabular}




\section{考察}

水痘罹患後におきる難聴について文献的にそ の発症頻度を調べると，本邦では切替ら ${ }^{7)}$ が調 査した 153 例の壟患者中 1 例が水痘による難聴 であり，小川 ${ }^{8}$ によると壟約 25000 例中水痘に よるあのは $1 \%$ 以下であったという。一方外国 では難聴巟 296 例中 3 例 97 ， 485 例中 6 例 ${ }^{10)}$ が水 痘によるという報告があり，水痘で入院した患 者247例中 6 例に感音難聴がみられたという ${ }^{11)}$. また突発難聴の原因としても水痘ウイルスが指 摘されて抢り，Jaffe ${ }^{12)}$ によると突発難聴患者 143例中 1 例, Tieri ら ${ }^{13)}$ による上小児の突発難 聴患者38例中 2 例が水痘によるあのであったと いう．いずれ屯非常に低い頻度であるが，水痘 による難聴は日常臨床でみのがされていたり， またあってあ報告されていない可能性があると の指摘もある ${ }^{14)}$.

しかしながら上記の報告では各症例に関する 記載がほとんどなく，乙れらからは水痘による 難聴の臨床像がはっきりしない。一方水痘に よる難聴について詳しく述べた症例報告となる と，乙れはきわめて数少ない，著者らが検索し たかぎりでは本邦には 1 例も報告がなく，外国 でわずかに 2 例の報告をみるのみである. 1978 年に Smith ${ }^{15)}$ が報告した25歳の男性は水痘罹 患後に両側の感音難聴をきたし，難聴は改善し なかった。1984年の Bhandari ら ${ }^{16)}$ の報告は14 力月の男児で，両側高度難聴のため ABR が無 反応で平衡障害屯出現した。難聴は改善しなか った．その他には前述の Tieri ら ${ }^{13)}$ の報告中に 2 症例の簡単な記載があり，6歳㧍よび 7 歳の 男児でいずれも一側の中等度および高度の感音 難聴で，難聴の経過は不変であった。乙れらの 報告をみると水痘による感音難聴は一般に中等 度あるいは高度で両側性のととも一側性のとと ああり，改善しにくい傾向にあると思われる.

水痘に関係した側頭骨病理については，水痘 後の難聴症例の報告はみあたらなく，わずかに Bordley ら ${ }^{11}$ による水痘で死亡した 4 症例の報 告があるのみである。乙れによると 4 例中の 1
例には病変は認められなく, 残る 3 例では中耳 に高度の炎症が認められた。このうちの1例は 迷路炎を合併していたが，残る 3 例には内耳病 変を認めなかった。 したがっててれら 4 症例で はウイルス感染に直接起因する内耳病変は認め られなかったと考えられる。この報告はむしろ 水痘による難聴には中耳炎によるものがあるこ とを示している，実際に Bordley ら"1)は同じ報 告の中で水痘で入院した患者 247 例中 $13.8 \%$ K 伝音難聴を認めたと述べているが，乙れは水痘 に合併した中耳炎によるものと思われる。実際， 水痘に㧍ける難聴は中耳炎の合併により生じた あのであると考える報告屯あり ${ }^{17) ，}$ 水痘ウイル スによる感音難聴の発症はめずらしいと考えて よさそうである。

ここで本症例を振り返ってみると，水痘罹患 後に母親が難聴に気付き, 当科受晾時にはほと んど一側壟に近かった，水痘ウイルスの抗体価 は32倍と高く，臨床症状より水痘罹患は間違い ないと考えられる．本症例では水痘の前に渗出 性中耳炎に罹患しており，乙の時のオージオグ ラムで治療後に難聴はないととが確認されてい る (図 1 B ). したがって本症例の難聴は滲出 性中耳炎とは関係なく，水痘罹患により発症し たととがわかる。一般に小児では難聴の発症時 期がはっきりしないことが多いことを考えると， 本症例のように難聴の発症がオージオグラムで 確認できてその原因を臨床的に特定できたとと は，幸運ではあるがきわめて重要なことである． この点でも本症例はとりわけ貴重な症例である。 本症例に抢ける難聴の臨床的特徴は一側性の ほとんど犝に近い高度感音難聴であり，治療 に反応を示さなかった。 これは一般にムンプス 難聴の典型とされる臨床像ときわめてよく似て いる ${ }^{18)}$ 。ムンプス難聴の蝸牛における病態はウ イルスの血行感染による内リンパ膜迷路の諸組 織の変性であるとのヒト側頭骨病理の報告があ るが(19)，乙のような内リンパ腔に限局した viral labyrinthitis は他のウイルス性難聴の多くに共 通してみられる ${ }^{20)}$ 。前述のように水痘による難 
聴の側頭骨病理報告はないが，本症例において あその臨床像の類似からムンプス難聴の場合と 同様な viral labyrinthitis が難聴の病態であろ うと推測されよう。一方, 主として成人に発症 する耳性帯状泡疹の側頭骨病理所見では神経に 沿った細胞浸潤や外リンパ腔の病変が報告され ている33)。乙れらは上記のムンプス難聴など における膜迷路の viral labyrinthitis の所見之 は異なっており，原因は同じウイルスであって 屯水痘による難聴は耳性帯状泡疹の場合とはそ の病態を異にする可能性が考えられよう。しか しながらこの点をあきらかにするには，今後の 側頭骨病理報告の蓄積が必要である。

\section{結 語}

5 歳の男児に発症した水痘後の難聴症例を報 告した。難聴は左一側性でほとんど䆍に近い高 度の感音難聴であった。 その発症にはムンプス 難聴之似た機序が考えられた。文献的に検討す ると水痘による難聴の発症頻度は非常に低い之 思われ，その詳しい症例報告はきわめて数少な い. とくに本症例では水痘罹患前のオージオグ ラムが得られており，乙れは水痘により難聴が 発症したととの裏付けとして貴重である。今後 こうした症例の積極的な報告とその蓄積により， 水痘後の難聴の臨床像がより明らかになるもの と思われる。

稿を終えるにあたり本症例において水痘の診断と治 療を行い，貴重な情報を㧍寄せいただいた山口＼cjkstart寿医 師に感謝する。

本論文の要旨は第34回日本聴覚医学会において発表 した.

\section{引用文献}

1) 平井文久, 栫 博幸, 三好俊二 : 急性高度難聴を きたしたハント症候群症例の検討. 耳鼻 $34: 24$ 〜28, 1988.

2）柳原尚明, 䀘 清文, 湯本英二 : ハント症候群に おける難聴の検討．厚生省特定疾患急性高度難聴 調査研究班昭和 60 年度研究業績報告書. $\quad 73 \sim 76$ 頁, 1986.

3) Blackley B, Friedman I and Wright I : Herpes zoster auris associated with facial nerve palsy and auditory nerve symptoms. Acta Otolaryngol 63 : 533 550, 1967.

4) Zajtchuk JT, Matz GJ and Lindsay JR : Temporal bone pathology in herpes oticus. Ann Otol Rhinol Laryngol 81:331 338, 1972.

5) Paparella MM : Sensorineural hearing loss in children-nongenetic. Otolaryngology (ed by Paparella MM and Shumrick DA). pp 1707 1717, WB Saunders, Philadelphia, 1980.

6) Mckendall R and Klawans H : Nervous system complications of varicella-zoster virus. Handbook of Clinical Neurology, vol 30 (ed by Vinken PJ and Bruyn GW). pp 161 183, North Holland, Amsterdam, 1978.

7）切替一郎，戸塚元吉 : 感音系難聴に関する臨床的 研究, 第 1 編. 感音系難聴の原因之聴力型に就て の臨床統計的研究(其 2). 日耳鼻 $53: 383 \sim 391$, 1950.

8）小川喜代子：䆍啞に関する研究一龍学校児童生徒 の統計的観察一. 耳喉 33:951 963, 1961.

9) Bordley JE and Hardy WG: The etiology of deafness in young children. Acta Otolaryngol $40: 72 \sim 79,1951$.

10) Bordley JE : The problem of the preschool deaf child; diagnostic methods and the otologist's role in his rehabilitation. Laryngoscope $62: 514 \sim$ 520, 1952.

11) Bordley JE and Kapur YP : The histopathological changes in the temporal bone resulting from acute smallpox and chickenpox infection. Laryngoscope $82: 1477 \sim 1490,1972$.

12) Jaffe BF : Sudden deafness, an otologic emergency. Arch Otolaryngol 86 : 55 60, 1967.

13) Tieri L, Masi R, Marsella $P$, et al : Sudden deafness in children. Int $\mathrm{J}$ Pediatr Otorhinolaryngol $7: 257 \sim 264,1984$.

14) Jaffe BF : Viral causes of sudden inner ear deafness. Otolaryngol Clin North Am $11:$ 107 132, 1982.

15) Smith $P$ : Horseltap etter vannkopper. Tidsskr Nor Loegeforen $98: 621 \sim 622,1978$.

16) Bhandari $R$ and Steinman GS : Sudden deafness in chickenpox; a case report. Ann Neurol 13 : 
347, 1983.

17) Davis LE and Johnsson LG : Viral infections of the inner ear; clinical, virologic, and pathologic studies in humans and animals. Am J Otolaryngol $4: 347 \sim 362,1983$.

18）野村恭也, 神崎 仁, 古賀慶次郎, 他：ムンプス 難聴. 耳鼻臨床 $81 ： 41 \sim 47,1988$.

19) Lindsay JR, Davey PR and Ward PH : Inner ear pathology in deafness due to mumps. Ann
Otol Rhinol Laryngol 69 : 918 935, 1960.

20) Lindsay JR : Histopathology of deafness due to postnatal viral disease. Arch Otolaryngol 98 : 258 264, 1973.

(原稿受付 : 平成元年11月17日 原稿採択 : 平成元年12月 1 日 別刷請求先 : 原田勇彦

干113 東京都文京区本郷7-3-1

東京大学医学部耳鼻咽喉科学教室) 